\title{
DESCRIPTION OF THE LARVA OF THRAULODES SCHLINGERI (EPHEMEROPTERA, LEPTOPHLEBIIDAE)
}

\author{
Maria José Nascimento Lopes ${ }^{1}$ \\ Claudio Gilberto Froehlich ${ }^{2}$ \\ Eduardo Dominguez ${ }^{3}$
}

\begin{abstract}
The larva of Thraulodes schlingeri Traver \& Edmunds, 1967 is described and figured for the first time.
\end{abstract}

KEYWORDS. Leptophlebiidae, Thraulodes, Ephemeroptera, larva, Brazil.

\section{INTRODUCTION}

ULMER (1920) established the genus Thraulodes for an adult male from Colombia, described as Thraulus laetus by EATON (1883). Revisions were made by TRAVER \& EDMUNDS (1967) and ALLEN \& BRUSCA (1978); both proposed two groups of species, the first based on the genitalia of adults and the second on larval gill structures, but these groups do not agree with each other. Twenty-four species of Thraulodes are known from South America, and only six from Brazil: T. daidaleus Thew, 1960, T. itatiajanus Traver \& Edmunds, 1967, T. limbatus Navás, 1936, T. subfasciatus Navás, 1924, T. traverae Thew, 1960, T. ulmeri Edmunds, 1950 and T. schlingeri Traver \& Edmunds, 1967, this one known only from adults from Peru.

In the course of studies carried out from January to December 1989, in a 4th order stretch of Pedregulho creek, in an area within the Bom Jesus farm, Municipality of Pedregulho, State of São Paulo, 5145 young and mature larva and 953 adults of T. schlingeri were collected and deposited in the Invertebrate Collection of INPA (Instituto Nacional de Pesquisas da Amazônia, Manaus). Some larvae were reared, confirming the association of larvae and adults. The determination of the species was based on male genitalia and color pattern of the abdomen, in comparison to the original description.

1. Instituto Nacional de Pesquisas da Amazônia (INPA), CPEN, Av. André Araújo, 2936, Petrópolis, Caixa Postal 478, 69011-970, Manaus, AM, Brazil. (ferreira@inpa.gov.br)

2. Faculdade de Filosofia, Ciências e Letras de Ribeirão Preto, Departamento de Biologia, Av. Bandeirantes, 3900, 14040-901, Ribeirão Preto, São Paulo, Brazil. (cgfroeh@usp.br)

3. Facultad de Ciencias Naturales e Instituto Miguel Lillo, Miguel Lillo, 205, 4000, S.M. de Tucumán, Argentina. (mayfly@uumail.unt.edu.ar) 


\section{Thraulodes schlingeri Traver \& Edmunds, 1967}

(Figs. 1-15)

Last instar larva length: body, 7.5-8.5 mm; caudal filaments, 8.0-9.5 mm. General color light brownish-orange.

Head (fig. 1) brownish-orange with anterior yellow border; an open V-shaped black stripe from eyes to median ocellus, more distinct in females; scape and pedicel of antennae grayish, flagellum light yellow; ocelli black with whitish inner margin; dorsal part of eyes of male reddish brown to black, ventral part black; eyes of female black. Labrum (fig. 2) brownish yellow, central area with black mark, wider than clypeus; width 3 times its length; anterior margin with wide and shallow emargination; lateral margins rounded. Clypeus blackish. Mandible brownish yellow but central area grayish; incisors and molars yellowish orange; articulations darker; row of pectinate hairs (fig. 3) on apical third of outer margin extending to level of outer incisor; prosthecae well developed. Right mandible (fig. 4): outer incisor with 3 apical denticles; inner incisor with 2 apical ones and serrated outer margin (fig. 5). Left mandible (fig. 6): apices of both incisors with 3 denticles; molars with serrated ridges. Maxilla (fig. 7) flattened and rectangular, yellowish, translucent, external margin more brownish; grayish spot at base of palp; apical setae with reddish brown bases. Hypopharynx (fig. 8) pale yellow, but center of superlinguae brownish, apical setae yellow; lingua yellow, translucent. Labium (fig. 9) translucent yellow, apical setae brownish yellow.

Thorax: pronotum brownish orange, lighter antero-medially, translucent at lateral margins. Mesonotum dark brownish orange with paler central spot. Metanotum brownish orange, postero-lateral border darkened. Pleurae and sterna light brownish orange; sterna with central dark spot.

Legs: femora yellowish brown with dark spot at $c a .3 / 4$ of length; tibiae, tarsi and tarsal claws light yellow. Foreleg (fig. 10): femur with fringe of long hairs along outer margin; short bristles scattered on central half of dorsal surface, a few larger ones at distal dorsal edge; tibia with long outer setae and a row of short bristles along inner margin, apical bristles longer; tarsus with scattered hairs on outer margin and an apical pectinate bristle. Second leg (fig. 11): femur with fringe of long hairs and short bristles along outer margin; short bristles also along an oblique band and at inner margin; tibia with long outer setae and a row of minute bristles along basal inner two thirds of length. Hindleg (fig. 12): hair fringe and short bristles on distal half of outer margin; short bristles scattered on dorsal surface of femur; tibia with long hairs and short bristles along outer margin, very small bristles along inner margin and a longer bristle apically; tarsus with outer short hairs. Tarsal claw of foreleg with 8-9 denticles progressively larger apically (fig. 13).

Abdomen (fig. 14): terga light brownish orange; tergum 1 with lateral apical black spot; terga 2-6 with antero-lateral elongate black spots, those of tergum 6 convergent medially. Terga 7-9 slightly darkened at posterior border; tergum 10 darkened along center of posterior border. Posterior border of terga with row of spines. Postero-lateral spines on segments 2-9, small on segment 2. Sterna lighter in color than terga. Abdominal gills (fig. 15) present on segments 1-7, bilamellate and of similar shape in all segments; lamellae wide, asymmetrical, tapering abruptly along posterior margin to apical filament; length to width ratio 4-5:1; gills gray, darker on lateral and median tracheae, gill margins pale. 


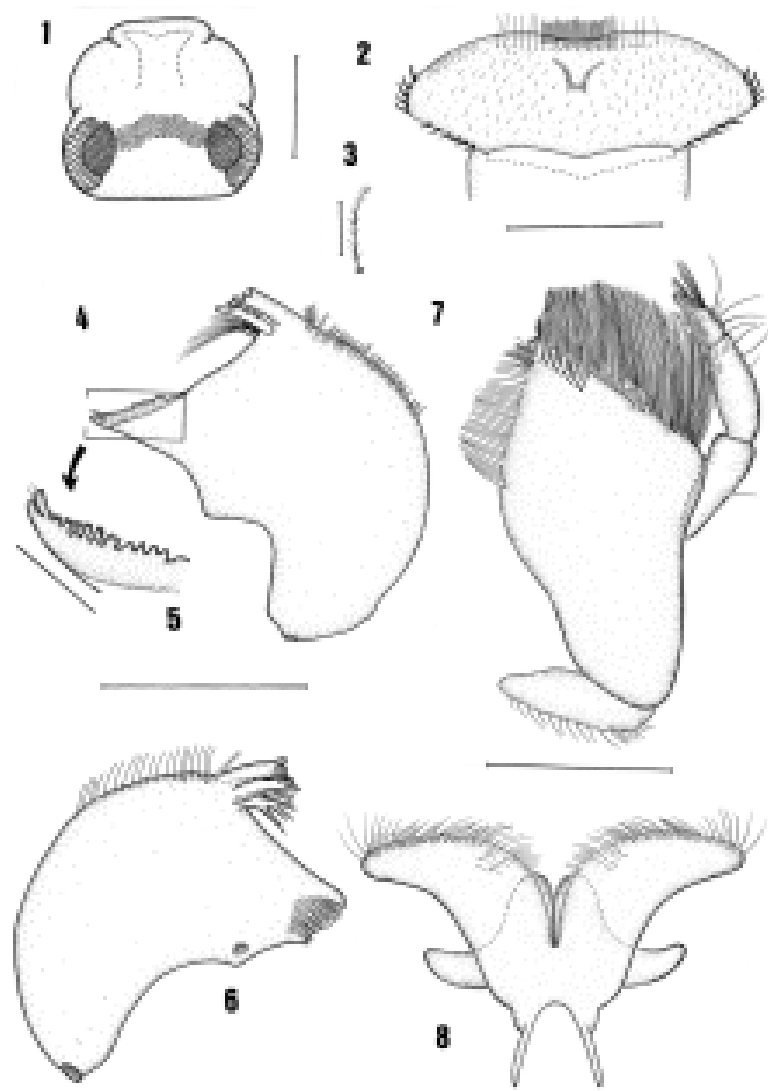

Figs. 1-8. Thraulodes schlingeri Traver \& Edmunds, 1967: 1, head, dorsal; 2, labrum, dorsal; 3, detail of the pectinate hairs of the mandibles; 4, right mandible, dorsal; 5, molar area of the right mandible; 6, left mandible, dorsal; 7, right maxilla, dorsal; 8, hypopharynx, ventral. Scale bars: fig. $1,1 \mathrm{~mm}$; figs. 3, 5, $0.05 \mathrm{~mm}$; figs 2, 4, 6-8, $0.5 \mathrm{~mm}$; same bars: 4, 6; 7, 8 .

Last instar larvae examined: BRAZIL, São Paulo: Pedregulho (Córrego do Pedregulho), 2 \%, one with mouthparts dissected out; $\varsubsetneqq$ with detached head; 16 ơ 23 q. All collected in September, 1989, M.J.N. Lopes, C.G. Froehlich \& L.G. Oliveira (INPA). The association was made by rearing mature larvae.

Biology. The larvae were collected in a riffle at $680 \mathrm{~m}$ a.s.l. The bed of the shallow stream was composed of boulders, cobbles and sand. Along the year, on sampling days and at $\mathrm{ca} .10 \mathrm{a} . \mathrm{m}$., temperature varied from $14^{\circ} \mathrm{C}$ in July to $24^{\circ} \mathrm{C}$ in November. Dissolved oxygen saturation values varied from $76 \%$ to $112 \%$ and $\mathrm{pH}$ from 5.1 to 6.8 .

Remarks. The larvae of $T$. schlingeri can be separated from the other known South American larvae of Thraulodes by the following combination of characters: abdominal gills with wide lamellae, and secondary traqueal gills well developed (fig. 15). It shares these characters with T. liminaris Dominguez, 1987 and T. consortis Dominguez, 1987, but can be separated from these two species by the presence of 8 to 9 denticles in the tarsal claws, that are progressively larger apically. Thraulodes liminaris presents only 6 denticles, progressively larger apically, and T. consortis 6 to 7 denticles, progressively 

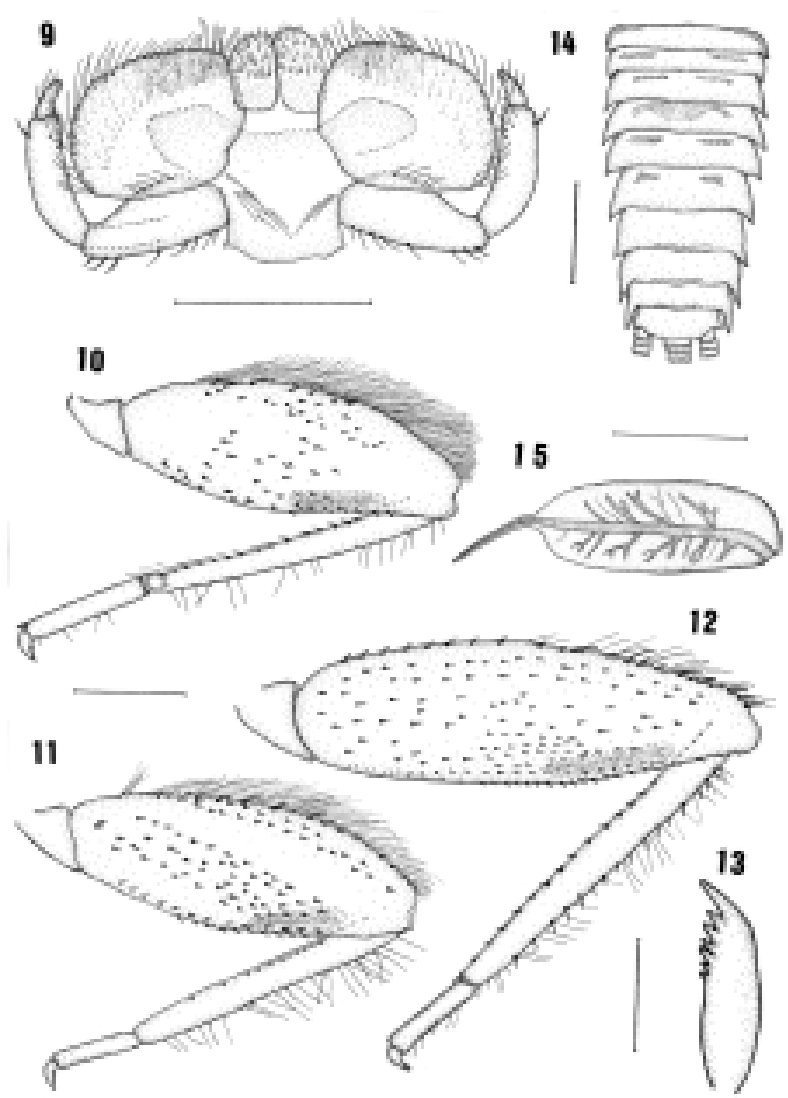

Figs. 9-15. Thraulodes schlingeri Traver \& Edmunds, 1967. 9, labium, ventral; 10, foreleg, dorsal; 11, second leg, dorsal; 12, hindleg, dorsal; 13, tarsal claw, lateral; 14, abdomen, dorsal; 15, abdominal gills. Scale bars: figs. 9-12, 15, $0.5 \mathrm{~mm}$; fig. $13,0.1 \mathrm{~mm}$; fig. $14,1 \mathrm{~mm}$.

larger apically, except distal one that is slightly larger. As these differences can sometimes be subtle, the abdominal color pattern should also be compared.

Acknowledgments. To Wilmar and Angela Gomes for permitting the study to be carried out on their property; to Dr. J. A. Rafael (INPA), for the optical equipment used.

\section{REFERENCES}

Allen, R. K. \& Brusca, R. C. 1978. Generic revisions of mayfly nymphs. II. Thraulodes in North and Central America (Leptophlebiidae). Can. Entomol., Ottawa, 110:413-433.

Eaton, A. E. 1883. A revisional monograph of recent Ephemeridae or mayflies. Trans. Linn. Soc.

Lond., Ser. Zool., London, 3:1-352, 65 pls.

Traver, J. R. \& Edmunds, G. F., JR. 1967. A revision of the genus Thraulodes (Ephemeroptera:

Leptophlebiidae). Misc. Pub. Ent. Soc. Am., Maryland, 5:349-402.

Ulmer, G. 1920. Neue Ephemeropteren. Arch. Naturgesch., Berlin, 85A(11):1-80.

Recebido em 14.10.2002; aceito em 17.02.2003. 